\title{
PERAN KOMPETENSI SOSIAL GURU PENDIDIKAN AGAMA ISLAM DI MADRASAH ALIYAH NEGERI KEMANTAN KABUPATEN KERINCI
}

\author{
Masnur Alam \\ Institut Agama Islam Negeri (LAIN) Kerinci \\ email: masnur.alam@yahoo.com
}

\begin{abstract}
Islamic Education teachers' social competence is still questionable and has not been done optimally and needs to be improved. The aims of this research are to find out how the role of social competence of the Islamic Education teachers' of Kemantan State Islamic School should be owned. Data and information are obtained from primary and secondary data from observations and interviews with Islamic Education teachers, as well as literature related to the focus of the study. The results of the study show that communication with Madrasah heads is generally good, but has not been done routinely. Communication with fellow teachers is still limited to subject group teachers. Communication with students has gone well, but is still oral and has not used communication in writing in the form of dictates / papers and electronic media. Communication with parents / guardians is still limited to parents living around madrasah. And communication with the community is still limited to madrasah committees and communities in their respective homes, and has not conducted research in the community.
\end{abstract}

Keyword: Social Competence, Islamic Education teachers 


\section{PENDAHULUAN}

Kompetensi sosial guru adalah kemampuan guru dalam berkomunikasi dengan siswa, guru, kepala sekolah, pegawai administrasi, anggota masyarakat sekitar. Dengan demikian kompetensi sosial guru merupakan salah satu kompetensi yang cukup urgen harus dimiliki, termasuk guru Pendidikan Agama Islam (PAI), karena dengan memiliki kompetensi sosial guru, ia dapat melakukan komunikasi, interaksi sosial, dan kontak sosial dengan semua pihak, terutama terhadap pihak yang berkaitan langsung dengan kegiatan pendidikan.

Dengan kompetensi sosial, guru akan mudah dalam menyelesaikan permasalahan siswa, serta dapat menerima informasi yang valid dari pihak yang berhubungan langsung dengan siswa tersebut, yang selalu mengamati tingkah laku, sikap dan perbuatan yang dihadapi siswa dalam kehidupan sehari-hari. Dari informasi tersebut akan dapat dijadikan pijakan dalam mengambil kebijakan serta solosi, pemecahan masalah yang dihadapi siswa sekarang ini yang semakin rumit. Dengan komunikasi yang baik diharapkan akan terjalin kerja sama, antara semua pihak terutama dalam meningkatkan kualitas pendidikan agama Islam di madrasah/sekolah yang sekarang ini selalu menjadi sorotan. Begitu juga dengan komunikasi akan dapat menambah keakraban, semangat kebersamaan antara guru dengan kepala sekolah, sesama guru, orang tua murid, dan masyarakat di sekitarnya. Sehingga pada akhirnya semua apa yang direncanakan dalam menangani permasalahan peserta didik akan dapat dilaksanakan dengan sebaik-baiknya.

Mengingat betapa urgennya kompetensi sosial tersebut, pertanyaannya bagaimana kompetensi sosial yang dimiliki oleh guru Pendidikan Agama Islam, apakah sudah sesuai dengan apa yang diharapkan. Berdasarkan hasil penelitial awal di MAN Kemantan Kerinci memang ditemui beberapa guru Pendidikan Agama Islam yang belum memiliki kompetensi sebagaimana semestinya, mereka masih terbatas pada komunikasi di lokal yaitu proses belajar mengajar. Begitu juga komunikasi dengan kepala sekolah belum dilakukan secara rutin, antara sesama guru agama dan guru lainya, belum terjadi koordinasi secara baik, apalagi komunikasi dengan orang tua dan masyarakat sekitarnya jauh dari yang semestinya. Dengan demikian kemampuan berkomunikasi guru Pendidikan Agama Islam masih perlu diperbaiki serta dapat ditingkatkan agar permasalahan yang dihadapi siswa berhubungan dengan Pendidikan Agama Islam dapat ditangani secara bersama-sama.

Berdasrkan fenomina di atas, dirasa perlu untuk dilakukan penelitian lebih lanjut agar dapat mengetahui lebih dalam tentang kondisi riil yang terjadi dilapangan, supaya diperoleh jawaban bagaimana kompetensi guru Pendidikan Agama Islam di MAN Kemantan, bagaimana 
upaya yang dapat dilakukan untuk meningkatkan kompetensi guru Pendidikan Agama Islam tersebut. Dengan demikian proses pembelajaran dapat menyenangkan, sehingga kualitas Pendidikan Agama Islam dapat meningkat, dan menjadi mata pelajaran yang diminati, disenangi dan menarik untuk didalami oleh siswa.

Secara khusus, kajian ini akan menganalisis beberapa fokus utama, yaitu bagaimana 1) komunikasi guru PAI dengan kepala madrasah, 2) komunikasi guru PAI dengan sesama guru/tenaga kependidikan, 3) komunikasi guru PAI dengan peserta didik, 4) komunikasi guru PAI dengan orang tua/wali, 5) komunikasi guru PAI dengan masyarakat sekitar.

\section{METODOLOGI PENELITIAN}

Penelitian ini di lakukan di Madrasah Aliyah Negeri Kemantan ((MAN) Kemantan, Kecamatan Air Hangat Timur Kabupaten Kerinci. Secara geografis madrasah ini sangat strategis, terletak di pinggir jalan dan mudah terjangkau oleh transportasi, kondisi iklim sejuk, aman dan nyaman untuk berjalannya proses pendidikan.

Subjek penelitian adalah Guru Pendidikan Agama Islam (GPAI) merupakan tenaga edukatif yang membidangi bidang studi: Qur'an Hadits, Fiqih, Akidah Akhlak, Sejarah Kebudayaan Islam (SKI) dan Bahasa Arab.

Penelitian ini bercorak deskriptif yaitu menggambarkan tentang komunikasi guru terhadap kepala madrasah, sesama guru, terhadap peserta didik, orang tua, dan masyarakat sekitar. Menurut Winarno Surakhmad ${ }^{1}$, metode deskriptif tidak terbatas hanya sampai pada pengumpulan dan penyusunan data, tetapi meliputi analisis dan interpretasi tentang arti data tersebut. Begitu juga yang akan dilakukan dalam penelitian ini, terhadap data yang ditemui akan dianalisis dan diinterpretasi bahkan berusaha memecahkan masalah serta mencari solusi. Sedangkan dimensi konseptuan metodologis yang dipakai dalam penelitian adalah induksi-generatif-konstruktif. ${ }^{2}$

Teknik pengumpulan data yang akan digunakan dalam penelitian ini adalah : a) observasi, yakni pengamatan partisifan dengan mengikuti semua kegiatan belajar baik di lokal maupun di luar lokal, peneliti melakukan observasi langsung untuk melihat kenyataan-kenyataan di lapangan secara holistik (utuh) dan dilakukan secara cermat, hati-hati, dan sungguh-sungguh. b) Interview, yakni wawancara bebas dengan membuat pedoman wawancara secara garis besar, yang dilakukan secara intensif dan berulang-ulang diharapkan peneliti bisa mendapatkan data dari informan secara luas, lengkap dan spontan. Wawancara selalu dikombinasikan dengan hasil pengamatan yang dianggap

${ }^{1}$ Winarno Surakhmad, Dasar dan Teknik Research, Pengantar Metodologi Ilmiyah, (Bandung, Tarsito, 1978),

${ }^{2}$ Noeng Muhadjir, Metode Penelitian Kualitatif,( Yokyakarta, Rakesarasin, 1996), h. 94 
belum tuntas dan masih diragukan untuk kebutuhan analisis, dan c) studi dokumen, yakni untuk memperoleh data berupa letak giografis, keadaan guru, keadaan siswa, keadaan sarana dan prasarana, struktur organisasi, visi dan misi. Setelah data dikumpulkan, maka untuk menjamin keabsahan data dilakukan triangulasi, yaitu untuk keperluan pengecekan atau sebagai pembanding terhadap data tersebut, dengan mengkonfirmasikan data hasil pengamatan dengan data hasil wawancara dan dokumentasi.

Setelah wawancara, observasi dan studi dokumen, selanjutnya dianalisis dan diinterpretasi secara kualitatif. Analisis data merupakan upaya mencari solusi dan menata kembali terhadap penyimpangan terhadap teori yang dilakukan oleh guru. Adapun proses analisis kualitatif yang dimaksudkan dalam penelitian ini dilakukan sejak pengumpulan data dengan langkah-langkah: pertama, mereduksi data, yakni proses menyeleksi, memfokuskan, menyederhanakan, mengabstraksikan, dan mentransformasikan data, sehingga menjadi sederhana dan mudah dipahami. Kedua, mendisplay data, atau proses mengklasifikasi data sesuai dengan kelompoknya, lalu ditafsirkan selanjutnya dibahas kembali atau diperkuat dengan mencari informasi tambahan, kemudian dianalisis dan diinterpretasi sebelum dibuat kesimpulan, dan ketiga menarik kesimpulan, yakni bagian akhir dari proses analisis data, diawali dari kesimpulan sementara, jika sudah teruji kredibilitas dan kekokohannya, baru dapat ditingkatkan menjadi kesimpulan akhir yang kuat, mengakar dengan kokoh, dan ini menjadi kesimpulan final.

\section{HASIL PENELITIAN DAN PEMBAHASAN}

\section{Hasil Penelitian}

\section{Komunikasi Guru PAI dengan Kepala Madrasah}

Berhubungan dengan salah satu tugas seorang guru adalah melaksanakan kegiatan proses pembelajaran secara efektif dan efesien, dan seorang guru tersebut bertanggung jawab langsung kepada madrasah atau sekolah, dalam hal ini adalah kepala madrasah atau kepala sekolah. Begitu juga sebagai salah seorang guru PAI yang merupakan bagian dari tenaga pendidik, di madrasah sudah barang tentu dituntut untuk selalu berkomunikasi dengan kepala madrasah sebagai atasannya. Berdasarkan hasil penelitian, serta hasil konfirmasi dengan salah seorang guru PAI Subhan $\mathrm{Kasim}^{3}$ beliau mengatakan memang saya kendatipun tidak terlalu sering namun sekali kali saya datang kepada kepala madrasah menyampaikan permasalahan yang dihadapi, terutama yang berhubungan dengan kondisi atau pengembangan kurikulum PAI., inovasi dalam proses pembelajaran terutama yang berhubungan dengan metode yang

${ }^{3}$ Subhan Kasim, Guru PAI (SKI dan Qur'an Hadis) MAN Kemantan, di Kemantan,Wawancara, tanggal 2 Mei 2017 
efektif dan efesien agar siswa mudah dalam memahami pelajaran PAI. Saat dikonfirmasi dengan kepala madrasah Andi Suyub ${ }^{4}$ beliau membenarkan bahwa guru PAI sa'at menghadapi permasalahan mereka datang untuk tukar pikiran agar masalah bisa selesai dengan cepat, saya selaku kepala madrasah selalu memberi arahan, dorongan, motivasi agar guru PAI selalu untuk meningkatkan disiplin, meliliki pengetahuan yang luas, meningkatkan profesionalitas, serta menjaga kualitas proses pembelajaran, agar hasil yang dicapai bisa lebih baik.

Begitu juga guru PAI yang lainnya Emilyati ${ }^{5}$ beliau mengatakan saya sering melakukan koordinasi dengan kepala madrasah bidang kesiswaan dalam merumus kegiatan yang bersifat ekstrakurikuler, diantaranya mengatur program pesantren kilat, peringatan hari besar Islam, lomba-lomba pidato yang Islami dan lain-lainnya. Hal ini diakui wakil kepala madrasah bidang kesiswaan Johandis ${ }^{6}$ bahwa, beliau sering bersama dengan guru PAI dalam menjadwalkan atau mengatur program kegiatan siswa yang bersifat Islami. Lebih lanjut dikatakannya kami selalu menyepakati terlebih dahulu apa yang akan direncanakan agar pelaksanaannya bisa lebih sukses sebagaimana yang diharapkan.

\section{Komunikasi Guru PAI dengan Sesama Guru/Tenaga Kependidikan}

Berdasarkan hasil wawancara dengan salah seorang guru PAI Maini Haryati ${ }^{7}$ diketahui informasi bahwa beliau memang selalu berkomunikasi dengan sesama guru. Apalagi di MAN Kemantan para majelis guru ditempatkan pada satu ruangan, maka dengan demikian akan semakin mudah untuk melakukan komunikasi, baik sebelum dan sesudah melaksanakan proses pembelajaran, maupun di sa'at jam kosong atau tidak mengajar.

Sa'at ditanyakan kepada siapa melaksanakan komunikasi ? Beberapa guru PAI mengemukakan kepada keseluruhan guru. Namun lebih dalam kepada guru Kelompok Mata Pelajaran PAI atau koordinator mata pelajaran PAI. Komunikasi ini lebih banyak membicarakan tentang kurikulum, pendalaman isi atau materi, kompetensi dasar, dasar kompetensi, tujuan, target capaian, metode serta media pembelajaran. Dengan komunikasi ini kami dapat berdiskusi, tukar pikiran serta mencari solusi terhadap permasalahan yang ditemui dalam mata pelajaran PAI (Aqidah Akhlak, Qur’an Hadis, Fiqih, SKI dan Bahasa Arab).

\footnotetext{
${ }^{4}$ Andi Suyub, Kepala MAN Kemantan, di Kemantan Wawancara, tanggal 2 Mei 2017

${ }^{5}$ Emilyati, Guru PAI (Fiqih) MAN Kemantan,di Kemantan, Wawancara, tanggal, 13 Mei 2017

${ }^{6}$ Johandis, Guru PAI (Fiqih) dan Kepala Madrasah Bidang Kesiswaan, di Kemantan, Wawancara, tanggal 15 Mei 2017

${ }^{7}$ Maini Haryati, Guru PAI (Aqidah Akhlak) MAN Kemantan, di Kemantan,Wawancara, tanggal, 20 Mei 2017
} 
Di samping itu dengan guru apa saja ? salah seorang guru PAI Arfan Efendi ${ }^{8}$ mengatakan tak kalah pentingnya dengan guru BK (Bimbingan Konseling) karena terhadap permasalahan yang dihadapi siswa biasanya diselesaikan melalui guru BK., maka kami sebagai guru agama juga merasa berkewajiban melakukan koordinasi dengan guru BK., serta ikut memberi bimbingan secara Islami terutama terhadap bimbingan akhlak, sopan santun, menghormati guru, saling menghormati sesama teman, tidak boleh bertengkar, membuat kerusuhan, tauran dan sebagainya.

Di samping itu sa'at ditanyakan apakah guru PAI juga melaksanakan komunikasi dengan tenaga kependidikan baik tenaga tata usaha, pustakawan maupun laboran ?. Salah seorang guru PAI mengatakan komunikasi dilakukan terutama dengan pegawai pustaka yang berhubungan dengan peminjaman buku-buku pelajaran/paket.

\section{Komunikasi Guru PAI dengan Peserta Didik}

Berdasarkan hasil penelitian serta observasi langsung, diketahui guru PAI di MAN Kemantan telah menunjukkan kompetensi yang baik dengan peserta didik, diantaranya telah melaksanakan proses pembelajaran secara profesional sesuai dengan keahlian yang dimilikinya agar terwujud siswa yang berkualitas dan berprestasi. Guru MAN bila dilihat dari bidang keilmuan yang diajar semuanya sudah sesuai dengan latar belakang pendidikan yang dimilikinya, dengan demikian akan memudahkan mereka untuk berkomunikasi dengan siswanya, karena segala permasalahan yang dihadapi dalam proses pembelajaran dapat diselesaikan dengan baik.

Namun diakui beberapa guru PAI (Fiqih dan SKI) ada yang mengajar PAI (QH), karena beberapa guru QH yang pindah tugas ke tempat lain, sedangkan penggantinya belum ada. Maka beberapa guru PAI yang kurang SKS lalu ditunjuk/ditugaskan untuk mengajar QH. Sa'at dikonfirmasikan terhadap guru yang mengajar Qur'an Hadis $(\mathrm{QH})$,apakah mengalami kesulitan ?. Mereka menjawab, tidak. Karena QH masih termasuk rumpun mata pelajaran PAI., tambah lagi mata pelajaran PAI pada umumnya banyak sekali berkaitan dengan landasan atau yang berdasarkan Al-Qur'an dan Hadis.

Begitu juga mereka telah melaksanakan fungsi sebagai pengajar, dapat mentransferkan ilmu pengetahuan agama Islam kepada peserta didik dengan baik, proses pembelajaran dapat berjalan dengan lancar, diskusipun terlihat hidup, peserta didik dapat bertanya secara bebas, sehingga proses pembelajaran dapat berjalan secara demokratis. Begitu juga guru PAI telah

\footnotetext{
${ }^{8}$ Arfan Efendy, Guru PAI (SKI dan Qur,an Hadis) MAN Kemantan, Wawancara, tanggal 22 Mei 2017
} 
melaksanakan tugas sebagai pemimpin kelas, mengelola agar lancarnya proses pembelajaran, mengatur agar proses diskusi menjadi lancar.

Sebagai guru PAI mereka juga sekali gus terlihat sebagai pembimbing dan konselor bagi peserta didik, seperti dalam menghadapi siswa yang bermasalah terhadap kesulitan belajar PAI itu sendiri. Namun bagi siswa yang mengalami permasalahan atau pelanggaran yang berhubungan dengan kedisiplinan, peraturan sekolah, merokok dan sebagainya, maka permasalahannya diserahkan kepada guru BK (Bimbingan dan Konseling) untuk menyelesaikannya. Walaupun demikian peran guru PAI tidak kalah pentingnya, selalu kerja sama dengan guru BK dalam menertibkan atau menkondusif suasana yang nyaman di lingkungan madrasah. Begitu juga kendatipun tidak secara maksimal, namun guru PAI pada suatu waktu juga sudah bertindak sebagai supervisor dalam memonitor kegiatan siswa sekali gus juga sebagai motivator, agar siswa dapat bersemangat dalam mengikuti setiap proses pembelajaran PAI dengan demikian kualitas pembelajaran PAI bisa menjadi lebih baik.

Berdasarkan hasil observasi, dalam berkomunikasi, terutama dalam pelaksanaan pembelajaran, guru PAI banyak menggunakan komunikasi yang bersifat lisan, berbicara secara langsung dengan siswa. Sebagian guru terlihat untuk memberi pemahaman kepada siswa sudah menggunakan dramatisasi, dengan gerak tangan, perubahan air muka, tinggi rendah suara. Bahkan sekali-kali menggunakan bahasa isyarat dalam pelaksanaan pembelajaran. Sebaliknya belum ditemui guru PAI yang menggunakan komunikasi dalam bentuk tulisan, seperti membuat bahan ajar dalam bentuk diktat, buku paket dan lain-lain. Dengan demikian tidak dapat diketahui sejauh mana kemampuan guru PAI dalam menulis, kelengkapan unsur tata bahasa, susunan, ketepatan pilihan kata dan kalimat, kebenaran kaedah ejaan dan pungtuasi.

Begitu juga guru PAI dalam menggunakan teknologi komunikasi dan informasi secara fungsional masih terbatas pada media cetak, seperti buku paket yang tersedia di madrasah, dan jarang sekali menggunakan media elektronik, internet sebagai sumber belajar, kecuali dalam mencari tugas-tugas yang diberikan guru PAI tersebut.

Berdasarkan hasil observasi diketahui bahwa guru PAI pada umumnya dapat bergaul secara efektif dengan peserta didik baik dalam proses pembelajaran di lokal, maupun di luar proses pembelajaran. Antara guru PAI dan siswa dalam beberapa waktu terlihat terjalin komunikasi yang baik, sehingga dengan demikian guru PAI dapat mengamati keberadaan atau kegiatan yang dilakukan oleh siswa sehari-hari.

Kendatipun demikian diakui guru PAI belum melakukan pembelajaran yang beragam dengan lokasi yang berbeda-beda, seperti belajar melalui wisata religius melihat bagaimana kebesaran ciptaan Allah, tapi masih dalam batas sekolah, madrasah atau lokal semata. 
Kontak hubungan guru PAI dengan peserta didik menurut Rafani' ${ }^{9}$ secara umum masih bersifat seperti hubungan guru dengan murid, dan belum sampai pada bentuk hubungan seperti bapak/ibu dengan anaknya. Tapi diakui hubungan mereka seperti hubungan kekeluargaan, karena memang diakui antara guru PAI dengan peserta didiknya ada yang mempunyai hubungan keluarga sebagai adik, kemenakan, ipar dan hubungan keluarga yang sangat dekat.

\section{Komunikasi Guru PAI dengan Orang Tua atau Wali}

Komunikasi dengan orang tua termasuk komunikasi nonformal. Menurut hasil wawancara dengan Handayani ${ }^{10}$ diketahui bahwa pada umumnya guru PAI mereka sering melakukan komunikasi dengan orang tua siswa, untuk mengetahui aktivitas yang dilakukan oleh muridnya di rumah, sekali gus untuk mengetahui bagaimana peran orang tua dalam membimbing anak-anak mereka. Namun karena kesibukan orang tua dalam kehidupan seharihari, sehingga guru merasa sulit untuk berkomunikasi secara rutin.

Diakui pula beberapa orang guru PAI yang mengatakan kami memang menyadari sebagai guru juga dituntut untuk selalu memperhatikan tingkah laku, perbuatan, sikap, dan perbuatan siswa di luar lingkungan sekolah yaitu dengan berkomunikasi dengan orang tua atau wali. Namun karena kesibukan orang tua siswa membuat kami kesulitan untuk berkomunikasi secara rutin, kami hanya dapat berkomunikasi dengan orang tua yang secara kebetulan tinggal di sekitar madrasah, dan tempat kami masing-masing.

Saat ditanyakan bagaimana pentingnya berkomunikasi dengan orang tua, sebagian besar guru PAI mengatakan karena dengan berkomuniksai tersebut kita dapat mengetahui bagaimana orang tua mereka memberi pendidikan agama pada anak-anaknya, karena orang tua adalah pendidik, pengasuh, atau guru pertama bagi anak-anak, dan keluarga merupakan madrasah pertama sebagai langkah awal untuk memasuki madrasah berikutnya, terutama yang berhubungan dengan pendidikan aqidah atau dasar-dasar iman (yang termasuk rukun iman), ibadah (sesuai dengan rukun Islam) dan ibadah-ibadah sunnat lainnya, dan begitu juga nilainilai akhlak, baik akhlak kepada Allah, Rasul, orang tua/keluarga, masyarakat dan pada diri sendiri. Orang tualah yang memiliki jam yang panjang untuk mendidik anak-anaknya, dengan dasar ini kami sebagai guru PAI di madrasah bisa menjadi patokan untuk kelanjutan pendidikan bagi siswanya.

\footnotetext{
${ }^{9}$ Rafani, Guru PAI (Aqidah Akhlak) MAN Kemantan, di Kemantan, Wawancara, tanggal,3 Juni 2017

${ }^{10}$ Handayani, Guru PAI (Fiqih) MAN Kemantan, di Kemantan, Wawancara, tanggal, 5 Juni 2017
} 
Saat didalami, apakah urgensi berkomunikasi dengan orang tua ada hubungannya dengan pendidikan akhlak atau moral peserta didik? Salah seorang guru PAI Rafani ${ }^{11}$ mengemukakan sudah pasti, karena ayah dan ibu (orang tualah) yang mempunyai tanggungg jawab besar dalam mendidik anak-anak dengan kebaikan dan dasar-dasar moral, mendidik anak-anak sejak kecil untuk berdisiplin, berkata benar, berlaku jujur, dapat dipercaya, istiqamah, mementingkan orang lain, menolong orang yang membutuhkan, berbuat baik kepada anak yatim, kaum fakir, tetangga dan lain-lain.

Dalam waktu yang bersamaan ditanyakan lagi bagaimana dengan pendidikan sosial anak ?. Guru PAI mengemukakan memang pendidikan sosial merupakan pendidikan yang dilakukan sejak usia dini, agar anak terbiasa menjalankan adab sosial yang baik, mengedepankan pertimbangan akal yang sehat dan melakukan tindakan yang bijaksana. Lebih lanjut dikatakan, melalui pendidikan sosial ini guru PAI dapat menimpa pengalaman dari orang tua dalam penanaman dasar-dasar penting pendidikan sosial tersebut seperti: pendidikan takwa, persaudaraan, saling kasih mengasihi, saling tolong menolong, sayang menyayangi, mengutamakan orang lain, toleransi, pemberi maaf, cinta damai dan kelembutan.

\section{Komunikasi Guru PAI dengan Masyarakat Sekitarnya}

Pada kompetensi sosial dengan masyarakat, sesuai dengan hasil observasi terlihat bahwa guru PAI juga telah menjalin komunikasi dengan masyarakat sekitarnya, dengan dunia luar, kendatipun dalam hubungan yang terbatas, seperti masyarakat sekitar madrasah, dan belum termasuk komunikasi secara luas dengan lembaga swadaya masyarakat maupun dengan dunia usaha, instansi pemerintah dan swasta. Komunikasi eksternal ini memang diakui mereka, merupakan bagian penting dalam rangka mensosialisasi program madrasah ke masyarakat sebagai pelanggan pendidikan, atau pemakai jasa lulusan setiap madrasah. Namun bagi guru PAI ada keterbatasan, karena secara luas di MAN Kemantan dalam hal hubungan madrasah dengan masyarakat sesuai dengan hasil wawancara dengan Wakil kepala madrasah bidang hubungan masyarakat (humas) Herri Suhandi ${ }^{12}$, dikatakan sebagian tugasnya yakni mengatur dan mengembangkan hubungan madrasah dengan masyarakat, termasuk diantaranya seperti dalam hal menyelenggarakan bakti sosial, bencana alam dan lain-lain.

Sedangkan dalam hal mengatur kerjasama dengan pihak luar, menurut Lukman Wahab $^{13}$ dilakukan oleh dewan pendidikan/komite madrasah, untuk menjalin hubungan

\footnotetext{
${ }^{11}$ Rafani, Guru PAI (Aqidah Akhlak) MAN Kemantan, Wawancara, tanggal 3 Juni 2017

${ }^{12}$ Herri Suhandi, Wakamad. Bidang Humas MAN Kemantan, di Kemantan, Wawancara, tanggal 20 Juni 2017

${ }^{13}$ Lukman Wahab, Komite Madrasah MAN Kemantan, di Kemantan,Wawancara, tanggal 19 Juni 2017
} 
dengan masyarakat agar saling memberi dan menerima informasi, sehingga masyarakat itu merasa bahwa mereka ikut bertanggung jawab dan menganggap bahwa madrasah merupakan miliknya yang perlu dipelihara, dipertahankan, dan dimajukan.

Dalam hal bergaul secara santun dengan masyarakat sekitar, semua guru PAI sudah melakukan dengan sebaik mungkin, mereka melakukan dalam rangka mentaati ketentuanketentuan yang berlaku di tengah masyarakat, mereka terlihat selalu mengindahkan norma serta sistem nilai yang berlaku atau adat istiadat dalam masyarakat.

Begitu juga mereka selalu menerapkan prinsip-prinsip persaudaraan Islam, jati diri sebagai pendidik, rasa tanggung jawab, serta menumbuhkan semangat kebersamaan, terutama dalam memberi contoh yang baik kepada peserta didik, dengan demikian diharapkan dapat menjadi pelajaran bagi siswa terhadap bagaimana pentingnya kebersamaan dalam mencapai tujuan yang mulia terutama di bidang PAI itu sendiri.

Berdasarkan informasi diketahui bahwa guru PAI belum banyak berkomunikasi dengan kelompok-kelompok sosial seperti kelompok bermain, olah raga, kesenian dan lainlain, kendatipun mereka menyadari ini merupakan tuntutan masa depan bagi seorang guru, namun mereka sudah banyak aktif dalam kelompok kegiatan agama seperti pengajian alim ulama, kelompok yasinan, barzanji, majlis taklim, remaja masjid dan lain-lain. Katanya dengan demikian akan membuka jalan bagi kami untuk berinteraksi, melakukan kontak secara luas dengan masyarakat.

Dengan kata lain diakui bahwa mereka telah melakukan interaksi sosial melalui komunikasi, dengan banyak komponen di tengah masyarakat, melalui informasi ini maka guru PAI dapat mengetahui berbagai masalah peserta didik di tengah masyarakat. Interaksi sosial merupakan hal yang sangat penting dalam kehidupan madrasah dan masyarakat, ia merupakan saripati kehidupan sosial yang tidak bisa ditinggalkan dalam membentuk peserta didik agar dapat berkompetensi atau bersaing di dunia global.

Dengan interaksi sosial terjadi kontal sosial yang dilakukan secara langsung, diantaranya melalui HP saling bertanya, saling memberi informasi antara satu dengan yang lainnya, sehingga antara mereka terjalin hubungan keakraban, persahabatan, kedekatan, kepedulian antara satu dengan yang lainnya. Sedangkan kontak sosial melalui media lain seperti surat menyurat, media cetak lainnya, radio, televisi dan sebagainya belum ada dilakukan.

Berdasarkan hasil wawancara dengan beberapa guru, diketahui bahwa terdapat guru PAI yang menjadi pelopor, perintis, penggerak, motivator di dalam pelaksanaan pembangunan di daerahnya, baik dalam pembangunan yang berbentuk fisik: madrasah, sekolah, masjid, 
mushalla, jalan, maupun yang berbentuk non fisik seperti: kegiatan keagamaan, penyuluhan agama, ceramah, dan khutbah.

Pada umumnya mereka juga mengakui ikut sebagai motivator dan inovator dalam pembangunan pendidikan agama Islam, menganjurkan agar masyarakat dapat memasukkan anak mereka untuk belajar agama, mencari pendekatan serta metode yang tepat untuk memudahkan dalam memahami agama, diharapkan demikian anak akan merasakan bahwa agama merupakan kebutuhan, penuntun, pedoman bagi manusia agar dapat selamat baik di dunia maupun akhirat.

Sebaliknya berdasarkan hasil wawancara, diperoleh informasi bahwa pada umumnya guru PAI belum melakukan penelitian di tengah masyarakat berkaitan dengan materi PAI bagaimana pemahaman, penghayatan dan pengamalannya oleh masyarakat, apalagi melakukan pengkajian secara mendalam dan komprehensif. Mereka masih menggunakan sumber-sumber yang terdapat dalam buku paket yang dikeluarkan/diterbitkan Kementerian Agama RI. Kemudian ditambah dengan buku-buku sumber lain yang dianggap mendukung berkaitan dengan topik inti sebagaimana terdapat dalam silabus PAI itu sendiri.

Lain halnya dengan tugas pengabdian pada masyarakat, menurut guru PAI, umumnya mereka sudah melaksanakan pengabdian pada masyarakat di Desa mereka masing-masing. Ikut berpartisifasi aktif dalam membangun Desa dengan berbagai kegiatan. Di samping itu juga kreatif dalam mencari hal-hal yang baru, mencari terobosan yang bisa dicontohkan oleh anggota masyarakat lainnya.

\section{PEMBAHASAN}

\section{Komunikasi dengan Kepala Madrasah}

Dalam rangka melaksanakan tugas dan tanggung jawab sebagai pendidik atau guru, memang seharusnyalah melakukan komunikasi, interaksi serta kontak terhadap pimpinan dalam hal ini kepala madrasah. Karena kepala madrasah merupakan figur kunci dalam perbaikan madrasah, sebagai kendali, pengontrol, dinamisator (penggerak), fasilitator yang terampil, visioner yang optimistik, manejer yang cerdas, maka beliau memerlukan informasi yang jelas tentang permasalahan yang dihadapi oleh bawahannya untuk mengambil kebijakan.

Jika guru PAI tidak dapat berkomunikasi dengan baik, memberi informasi yang valid, maka kebijakan yang diambil bisa tidak sesuai dengan kebutuhan riil. Kebijakan dan kewenangan kepala madrasah akan membawa pengaruh langsung kepada guru, siswa, orang tua dan masyarakat. 
Pentingnya berkomunikasi karena kepala madrasah memiliki kewajiban (responsibility) wewenang (authority), dan pertanggungjawaban (accountability) yang tinggi dalam meningkatkan kinerja terhadap semua pihak yang berkepentingan (stakeholders) termasuk dalam mengembangkan tugas dan wewenang guru.

Di samping itu kepala madrasah berfungsi sebagai pemantau terhadap kegiatan guru, baik yang menyangkut perencanaan dan persiapan dalam mengajar sekaligus sebagai suvervisor. Dengan lancarnya komunikasi dia akan dapat memberi masukan, arahan atau bimbingan (taujib), arahan kepada guru PAI dan akan selalu mengutamakan profesionalisme dengan berpedoman pada the right man on the right job, yakni menempatkan seseorang sesuai pada tempatnya. Dengan demikian hasil yang dicapai akan bisa lebih maksimal sesuai harapan.

\section{Komunikasi dengan sesama guru/tenaga kependidikan}

Ini merupakan komunikasi antara sesama teman atau komunikasi dua arah (dialog) yang merupakan konsep komunikasi yang harus dijunjung tinggi, ia lebih bernurani dan manusiawi. Guru secara profesional merupakan jabatan atau pekerjaan yang memerlukan keahlian khusus dan tidak dapat dilakukan oleh sembarang orang, dan bukan merupakan pekerjaan sambilan, tapi memiliki tanggung jawab bahkan mendahulukan kewajiban daripada hak karena dia merupakan penentu terhadap keberhasilan setiap usaha pendidikan. Artinya semakin berkualitas guru pada satu sekolah, maka semakin besar kemungkinan sekolah tersebut dalam mengeluarkan lulusan yang berprestasi. Dengan demikian guru dapat dikatakan sebagai ujung tombak pendidikan, merupakan tokoh sentral yang sangat berpengaruh dalam proses pembelajaran dalam upaya menyiapkan sumber daya manusia atau lulusan yang berkualitas.

Begitu juga komunikasi dengan tenaga kependidikan seperti tata usaha, konselor, pembina OSIS, pembina pramuka, bendahara, pustakawan dan laboran. Semuanya ini merupakan unsur yang cukup berperan serta mempunyai tugas dan tanggung jawab serta wewenang untuk mewujudkan madrasah yang berkualitas.

Satu hal yang tak kalah penting lagi yaitu komunikasi dengan pengawas. Pengawas bukan sekadar unsur yang mencari kesalahan, tapi pengawas merupakan pihak yang bertanggung jawab untuk menyayomi, melakukan arahan, perbaikan agar terciptanya kualitas proses pembelajaran. 


\section{Komunikasi dengan peserta didik}

Sebagai guru PAI harus dapat melaksanakan komunikasi dengan peserta didik baik dalam proses belajar mengajar maupun di luar proses belajar. Peserta didik juga disebut anak didik atau terdidik, atau sebagai individu/pribadi (manusia seutuhnya). Seorang pendidik harus memahami sebagai individu yang mempunyai sifat-sifat dan keinginan sendiri, memiliki sifat pribadi yang menentukan diri sendiri dan tidak dipaksa dari luar. Ia merupakan sosok anak yang bukan meniatur orang dewasa, maka dalam proses pendewasaannya peserta didik harus dipandang sebagai subjek bukan objek pendidikan. Seorang guru dalam hubungannya dengan peserta didik hendaklah laksana hubungan orang tua dengan anaknya, karena guru adalah orang tua peserta didik masing-masing. Maka sedapat mungkin dapat melakukan kontak sosial yang edukatif bagi anak didik.

\section{Komunikasi dengan orang tua/wali}

Dalam pendidikan Islam orang tua (bapak dan ibu) merupakan orang yang paling bertanggung jawab terhadap pendidikan anaknya mulai dari masa kelahiran, mencapai analisa, pubertas, dan sampai anak menjadi dewasa. Mendidik anak ini merupakan amanat dari Allah yang wajib dilaksanakan oleh orang tua. Dan hatinya yang suci itu adalah permata yang mahal. Apabila ia diajar dan dibiasakan pada kebaikan, maka ia akan menjadi baik dan mendapat kebahagiaan, apabila ia dibiasakan dengan kejahatan, maka ia akan sengsara dan binasa. Bahkan orang tua dan wali harus memilihkan para guru dan pendidik untuk anak-anak mereka, sehingga mampu menjalankan tugas dengan sebaik-baiknya di dalam membina anak-anak terutama tentang aqidah, ibadah, dan akhlak mulia.

Pendidikan Islam sangat mengutamakan pendidikan keimanan pada masa pertumbuhannya, agar setelah tumbuh dewasa iman menjadi sempurna dan mantap, aqidah menjadi dalam, sehingga ia tidak akan tergoyahkan, tidak murtad, tidak akan terpengaruh oleh propaganda, tidak akan terjadi penyimpangan. Dalam membina ini memang bermula dari keluarga, orang tua biasanya menggunakan metode sosialisasi berjenjang, yang dimulai dari halhal yang dapat dicernakan dengan menggunakan indera, meningkat kepada hal-hal yang bersifat global, dan dari hal-hal yang sederhana meningkat kepada hal-hal yang tersusun secara sistematis. Hingga akhirnya orang tua, dapat mengantarkan anak-anak kepada iman dengan cara yang logis dan argumentatif. Untuk memberikan nasehat imani ini, hendaknya benarbenar diperhatian oleh pendidik pertama yaitu orang tua. Orang tua merupakan sumber segala keutamaan dan kesempurnaan. 
Bahkan ia merupakan pusat segala sumber, karena anak telah memasuki pintu gerbang iman dan meniti jembatan Islam. Tanpa iman tidak akan terwujud suatu keadilan, manusia senantiasa membutuhkan iman seperti halnya mereka membutuhkan air dan udara. Begitu juga pendidikan ibadah, ini dalam rangka membiasakan anak untuk selalu tunduk dan patuh terhadap bentuk-bentuk ibadah baik dalam bentuk vertikal maupun horizontal. Kenikmatan dalam beragama sangat ditentukan oleh ketaatan beribadah kepada Allah SWT. Apalagi ibadah tersebut sudah dapat dilaksanakan dengan khusyu'. Ibadah ini memerlukan latihan dan pembinaan dan arahan sejak usia dini. Dengan latihan yang terus menerus, arahan yang lurus, maka dalam jangka waktu yang relatif singkat orang tua sudah mampu menciptakan generasi muslim yang kuat dan kokoh. Iman mempunyai pertalian yang erat dengan ibadah, laksana pohon dengan buahnya, tidak ada artinya pohon yang rindang tapi tidak memiliki buah.

Sebagai kelanjutan dari pendidikan iman dan ibadah adalah pendidikan akhlak mulia yang berbentuk perangai dan tabiat atau perbuatan. Dengan modal iman akan dapat meluruskan tabiat yang bengkok dan memperbaiki jiwa kemanusiaan seseorang. Antara iman dengan moral dan akidah dengan perbuatan memiliki pertalian yang erat. Akhlak atau moral itu tidak akan tercipta tanpa adanya tiga keyakinan: yakni keyakinan adanya Tuhan, kekalnya ruh dan adanya perhitungan setelah mati.

\section{Komunikasi dengan masyarakat sekitar}

Masyarakat adalah unsur yang harus diperhatikan secara luas bagi seorang guru, karena masyarakat merupakan salah satu ruang lingkup pendidikan terutama pendidikan nonformal. Fungsi pendidikan di sekolah sedikit banyak dipengaruhi oleh corak pengalaman seorang di lingkungan masyarakat, karena di tengah masyarakat terdapat lembaga-lembaga pendidikan, kursus-kursus, latihan-latihan yang sangat menunjang pendidikan formal dan informal. Pengaruh pendidikan nonformal memiliki nilai yang besar dalam melahirkan seorang individu anak, oleh karena demikian, untuk mengamati dunia pendidikan tentu tidak cukup hanya dengan melihat masalah internal pendidikan, namun perlu pula melihat beberapa komponen lain, misalnya: sosial, budaya, ekonomi, politik, sejarah, filsafat, agama, etnis dan lainnya.

Guru PAI harus memiliki jangkauan yang luas, mendukung lingkungan sekitar sebagai aspek yang ikut serta dalam meningkatkan kualitas pendidikan. Masyarakat modern sekarang adalah masyarakat yang sudah mampu menyediakan sumber belajar, media belajar secara global, seperti menyediakan media belajar yang menggunakan jasa internet, e-learning dan $e$ books, serta didukung dengan suatu sistem perangkat lunak (software) dan perangkat keras (hardware) yang relevan. 
Guru PAI sudah seharusnyalah berkomunikasi aktif dengan masyarakat sekitar, menjadikan masyarakat sebagai tim kerja sama (partners) dalam mendidik dan mengembangkan pendidikan anak didik, dan ini memang merupakan hak masyarakat untuk berperan serta dalam memperoleh informasi tentang perkembangan pendidikan di sekolah.

Hubungan timbal balik antara sekolah dan masyarakat sangat besar manfaat. Maka elemen-elemen sekolah, terutama kepala sekolah dan guru-guru, merupakan kunci keberhasilan yang dapat diandalkan untuk menyatu, menghubungkan antara keduanya. Guru PAI harus banyak mengenal lingkungan sosial tempat mereka berada agar dapat memahami latar belakang kultural anak didik.Jika dicermati masyarakat dan lingkungannya sangat kaya informasi yang dapat mendukung kegiatan belajar mengajar, serta dapat menjadikan masyarakat sebagai sumber belajar. Guru PAI dituntut berupaya membina dan mengembangkan hubungan kerjasama konstruktif antara sekolah dengan masyarakat guna mewujudkan sekolah yang efektif, efisien dan produktif.

Dalam berkomunikasi menurut pendidikan Islam terutama dalam bentuk komunikasi lisan yang paling penting harus diperhatikan adalah komunikasi dengan perkataan yang terbaik dan kalimat (thayyibah) perkataan yang enak, manis, indah, menenangkan jiwa, tidak membahayakan, dapat menimbulkan rasa aman dan ketenangan. Begitu juga hendaklah mengucapkan qaulan sadidan, benar atau lurus dan jujur dalam komunikasi. Terdapat unsur kebenaran (right), kejujuran (bonesty), keadilan (just), dan perkataan lurus (straibt word) dalam materi komunikasi, dengan arti kata tidak boleh berbohong, menyeleweng kebenaran, baik untuk menyembunyikan dengan "membuang informasi yang benar" maupun memalsukan, "menyajikan informasi palsu seolah-olah informasi itu benar".

Begitu juga berhubungan dengan perasaan komunikan, maka cara penyampaian adalah qaulan ma'rufan perkataan lemah lembut dan baik, termasuk perbuatan baik serta perlakuan baik, di hadapan dan di belakang komunikan. Qaulan ma'rufan berarti kata-kata yang menyenangkan dan tidak berlawanan dengan sopan santun. Selain ini terdapat juga kata qaulan layyinan (gentle word), lemah lembut, busnan (kindly), yang baik, balighan (effektive), membekas pada jiwa, maysura (simplicity), lemah lembut.

Sebagai sinonim dari komunikasi dalam pendidikan Islam adalah dakwah, karena antara dakwah dan komunikasi memiliki sasaran dan tujuan yang sama dari segi media (sarana) dan dari segi target sasaran, yaitu sebagai tindakan amar makruf dan nabi munkar. , Menyuruh/perintah (berbuat) yang makruf dan mencegah/melarang dari yang munkar, baik dari sisi perkataan maupun perbuatan. Kita diperintahkan untuk melakukan ucapan dan perbuatan yang makruf atau sesuatu yang diredhai Allah, dan sebaliknya mencegah melakukan 
sesuatu yang tidak diredhai Allah. Ini dilakukan dalam rangka mengubah, semacam usaha atau tindakan pelurusan, mengembalikan keposisi yang benar, agar seseorang tidak larut dalam kesesatan. Perubahan dapat terjadi apabila ada kehendak untuk berubah. Kehendak untuk berubah dalam hal ini adalah melalui "proses belajar" (learning), "sikap terbuka" dan mau menerima "sesuatu" yang baru (komunikasi melalui informasi dan dakwah melalui tabligh). Masyarakat Islam adalah masyarakat yang selalu ingin melakukan perubahan (change) ke arah yang lebih baik (positif) dan mencegah berbagai perbuatan negatif.

Bentuk komunikasi yang lain adalah akhlak atau tradisi baik, sifat baik, kata-kata bijak, atau perilaku sosial yang berlaku berdasarkan pengetahuan yang bersumber pada pengalaman, yang mendekati istilah wisdom dalam tradisi sosial Barat. Dengan tegas dapat dikatakan bahwa term dakwah dalam pendidikan Islam berarti komunikasi dalam kajian ilmu sosial. Kata tabligh diartikan informasi, amar makruf nabi munkar diartikan perubahan (change) dan pembangunan (development), kata akblak hasanab/etik dikenal dengan wisdom dalam ilmu sosial.

\section{PENUTUP}

Pada umumnya guru PAI di MAN Kemantan telah melakukan komunikasi dengan kepala madrasah, sebagai komunikasi vertikal, untuk berkomunikasi tentang permasalahan yang dihadapi. Kepala madrasah telah merespons serta memberi arahan, motivasi serta saran untuk meningkatkan kualitas proses pembelajaran PAI tersebut.

Sebagian besar guru PAI telah berkomunikasi dengan sesama guru/tenaga kependidikan. Namun interaksi serta kontak lebih banyak terfokus kepada guru mata pelajaran PAI dalam rangka upaya mencari solusi terhadap permasalahan pembelajaran PAI. Di samping itu tak kalah pentingnya komunikasi terhadap guru Bimbingan Konseling (BK) untuk menyelesaikan siswa bermasalah.

Komunikasi guru PAI dengan peserta didik pada umumnya sudah berjalan dengan baik. Seluruh guru PAI mengajar sesuai dengan latar belakang pendidikannya dan mereka sekali gus sebagai pembimbing dan konselor bagi siswa. Namun dalam hal pelaksanaan pembelajaran, guru PAI belum maksimal dalam menggunakan media pembelajaran seperti media cetak, elektronik, in fokus, internet dan sumber belajar lainnya.

Komunikasi guru PAI dengan orang tua murid belum merata dan maksimal, tapi masih terbatas pada orang tua yang berada di lingkungan madrasah, dan tempat tinggal guru masingmasing. 
Guru PAI dalam melaksanakan komunikasi dengan masyarakat, masih terbatas pada komite madrasah serta belum meluas kepada kelompok sosial secara luas. Namun sebagian besar telah ikut serta dalam kegiatan masyarakat seperti pengajian ulama, kelompok yasinan, barzanji, majelis ta'lim, serta ikut berpartisifasi serta aktif sebagai pelopor, perintis, penggerak, motivator dalam pembangunan dalam daerah masing-masing.

\section{REFERENSI}

Abdullah Idi. (2011). Sosiologi Pendidikan, Individu, Masyarakat, dan Pendidikan, Jakarta: Raja Grafindo Persada

Ahmad Mustafa Al-Maraghi.(1974). Tafsir Al-Maraghi, Dar Al-Fikr

Abu Ahmadi. (2002). Psikologi Sosial, Jakarta: Rineka Cipta

Andi Faisal Bakti. (2000). Islam and Nation Formation: From Communitarian to Organizational Communications, Jakarta: Logos

Anwar Arifin. (2013). Ilmu Komunikasi Sebuab Pengantar Ringkas, Jakarta: Raja Grafido Persada

Arni Muhammad. (2007). Komunikasi Organisasi, Jakarta: Bumi Aksara

Dedi Darmawan dan Asra. (2012). Teknologi Informasi \$ Komunikasi, Jakarta: Dirjen Pendidikan Islam Kemenag RI.

Fachruddin Saudagar dan Ali Idrus. (2009). Pengembangan Profesionalitas Guru, Jakarta: GP. Press

Hafied Cangora. (2000). Pengantar Ilmu Komunikasi, Jakarta: Raja Grafindo Persada

Ibnu Taimiyah. (1984). Al-'Amru Bi Al-Ma'ruf wa Nabi al-Munkar, Beirut: Dar Al-Kitab AlJadid

M. Tata Taufik. (2012). Etika Komunikasi Islam, Bandung: Pustaka Setia

Mukhtar dkk. (2001). Sekolah Berprestasi,Jakarta: Nimas Multima

Noeng Muhadjir. (1996). Metode Kualitatif, Yokyakarta: Rekasarasih

Suharsimi Arikunto. (1990). Manajemen Pengajaran Manusiawi, Jakarta: Rineka Cipta

Sukmadinata. (2000). Pengembangan Kurikulum, Teori dan Praktek, Bandung: Remaja Rosdakarya

Unang Uchjana Effendy. (2013). Komunikasi Teori dan Praktek, Bandung: Remaja Rosdakarya

Winarno Surakhmad. (1978). Dasar dan Teknik Researh, Pengantar Metodologi Ilmiyah, Bandung: Tarsito 